\title{
CELIAC DISEASE IN CHILDREN FROM MADEIRA ISLAND AND ITS PREVALENCE IN FIRST DEGREE RELATIVES
}

\author{
Joana Raquel Henriques OLIVEIRA ${ }^{1}$, António Jorge CABRAL ${ }^{1}$, Elena FERREIRA ${ }^{1}$, \\ Filipa CAPELINHA ${ }^{2}$, Hélder SPÍNOLA ${ }^{3}$ and Rute GONÇALVES ${ }^{1}$
}

\begin{abstract}
Context - It is well recognized that celiac disease is an immune-mediated systemic disorder highly prevalent among relatives of celiac patients. Objectives - The aim of this study is to determine the prevalence of celiac disease in a group of first degree relatives of celiac children, and to access the frequency of human leukocyte antigen HLA-DQ2 and DQ8 in celiac disease patients and their affected relatives. Methods - A survey was conducted of 39 children with celiac disease with follow-up in the Pediatric outpatient's clinic of Dr. Nélio Mendonça Hospital, in Madeira Island, Portugal. Were invited 110 first degree relatives to undergo serological screen for celiac disease with IgA antibody to human recombinant tissue transglutaminase (IgA-TGG) quantification. In all seropositive relatives, small intestinal biopsy and HLA typing was recommended. Results - HLA- typing was performed in 38 celiac patients, $28 / 74 \%$ DQ2 positive, $1 / 2 \%$ DQ8 positive and 9/24\% incomplete DQ2. Positive IgA-TGG was found in five out of the 95 relatives, and CD was diagnosed in three of them. Three relatives had the presence of HLA-DQ2, two were DQ2 incomplete (DQB1*02). Conclusion - The prevalence of celiac disease among first degree celiac patients' relatives was 3.1\%, 4.5 times higher than the general Portuguese population $(0,7 \%)$ witch reinforces the need of extensive diagnostic screening in this specific group. HLA-DQ2 typing may be a tool in the diagnostic approach.
\end{abstract}

HEADINGS - Celiac disease. Child. Genetic predisposition to disease. HLA antigens.

\section{INTRODUCTION}

Celiac disease (CD) is an immune-mediated systemic disorder elicited by gluten in genetically susceptible individuals and characterized by the presence of a variable combination of gluten dependent clinical manifestations, $\mathrm{CD}$-specific antibodies, human leukocyte antigen (HLA)-DQ2 or DQ8 haplotypes and enteropathy.

$\mathrm{CD}$ is considered one of the most common autoimmune conditions with prevalence that vary from $0,5 \%-1 \%$ in the general population of countries worldwide $^{(1,3,4,5,6)}$. A study conducted in Portugal found a prevalence of $0,7 \%{ }^{(2)}$. Several studies reported an increasing prevalence of $\mathrm{CD}$ in the general population, related to the increasing recognition of the disease and the availability of serologic markers.

For initial testing, a quantitative test detecting total $\operatorname{IgA}$ and $\operatorname{IgA}$ antibody to human recombinant tissue transglutaminase (IgA-TTG) or identification of anti-endomysium antibodies (EMA) from a blood sample is recommended. Identification of EMA is currently considered as the reference standard anti- body test for $\mathrm{CD}$, however it can suffer inter-observer variability and is more expensive.

A small intestinal biopsy should be performed so as to clarify whether $\mathrm{CD}$ is present or not, but histological assessment may be omitted in symptomatic cases who have high IgA-TTG levels, EMA positivity, and are HLA-DQ2 and/or DQ8 heterodimer positive ${ }^{(7)}$.

More than $95 \%$ of CD patients share the HLADQ2 heterodimer, either in the cis (encoded by HLA-DR3-DQA1*0501-DQB1*0201) or in the trans configuration (encoded by HLA DR11-DQA $1 * 0505$ DQB1*0301 / DR7- DQA1*0201 DQB1 0202) and most of the remainder have the HLA-DQ8 (encoded by DQA $1 * 0301-\mathrm{DQB} 1 * 0302)^{(8)}$. The presence of one chain of the DQ2 heterodimer (DQA $1 * 05$ or DQB1*02, but not both) accounts for an increased risk of $\mathrm{CD}^{(8)}$.

Typing for HLA-DQ2 and HLA-DQ8 is a useful tool to exclude $\mathrm{CD}$ or to make it very unlikely in case of a negative antibodies test result. HLA testing may be offered to asymptomatic at-risk groups to select them to further CD specific antibody testing.

$\mathrm{CD}$ testing is recommended in symptomatic pa-

Declared conflict of interest of all authors: none

${ }^{1}$ Pediatrics Department. Hospital Dr. Nélio Mendonça, Funchal, Portugal; ${ }^{2}$ Pathology Department. Hospital Dr. Nélio Mendonça, Funchal, Portugal; ${ }^{3}$ Human Genetics Laboratory, University of Madeira, Funchal, Portugal.

Correspondence: Joana Raquel Henriques Oliveira. Hospital Dr. Nélio Mendonça. Avenida Luís de Camões - $9004-514$ - Funchal, Madeira, Portugal. E-mail: oli. joana@gmail.com 
tients and in at-risk groups who account for a higher CD prevalence, such as autoimmune diseases (especially type 1 diabetes and thyroiditis) IgA deficiency, some genetic syndromes (Down, Turner and Williams syndrome) and first degree-relatives of celiac patients. Previous studies regarding screening of first degree relatives have shown prevalence of $\mathrm{CD}$ in the range of $2.8 \%-10 \%(1,3,5,12,15)$.

Madeira is an island of Portugal with 267,785 inhabitants, 53,988 under the age of 18 years.

The objective of the present study is to determine the prevalence of $\mathrm{CD}$ in a group of first degree relatives of celiac children, and to access the frequency of HLA-DQ2 and DQ8 in $\mathrm{CD}$ patients and its affected relatives. To date, this is the first pediatric celiac disease prevalence study with genetic characterization in Portugal.

\section{MATERIALS}

\section{Population and design}

A survey was conducted of 39 children with celiac disease with follow-up in the Pediatric outpatient's clinic of Dr. Nélio Mendonça Hospital, the Hospital that gives assistance to the entire Island. HLA typing was performed in this population. The diagnosis of CD index patients was based on the European Society for Pediatric Gastroenterology, Hepatology and Nutrition (ESPGHAN) guidelines for the diagnosis of celiac disease in children and adolescents ${ }^{(7)}$.

First degree relatives of these 39 children were invited to undergo serological screen for CD, from September 2010 to October 2011. All first degree relatives were questioned with regards to the presence of $\mathrm{CD}$ related diseases (such as autoimmune thyroiditis, diabetes mellitus, Down syndrome), and presence of gastrointestinal or non-gastrointestinal symptoms of CD. All family members were on gluten-containing diet when serologic tests were performed. In all seropositive relatives, small intestinal biopsy and HLA typing was recommended.

The present study was approved by the Hospital Ethics Committee, according to the Declaration of Helsinki. All subjects were informed about the objectives of the study and the eventual necessity for small bowel biopsy and genetic HLA typing. Informed consent was obtained from adults and from the parents of the siblings.

This study had the collaboration of the Laboratory of Human Genetics of the University of Madeira.

\section{Serologic markers and small intestinal biopsy}

The serologic screening was based on total $\operatorname{IgA}$ and IgA-TTG determined by chemiluminescent immunoassay in samples of human serum or plasma (EDTA, heparin), being $10 \mathrm{AU} / \mathrm{mL}$ the upper normal limit range determined by the manufacturer (ZENIT RA t-TG IgA test - A. Menarini diagnostics).

Small intestinal biopsy was performed by endoscopy procedure with two fragments being taken from the bulb and three or four samples from the distal duodenum.

All biopsy specimens were blindly evaluated by a pathologist and classified according to Marsh-Oberhuber classifica- tion $^{(11)}$ Briefly, type 0 lesion indicates normal histology; type I is characterized by an increased number of intraepithelial lymphocytes (greater than 30 limphocytes per 100 enterocytes) in an architecturally normal intestinal mucosa; type II presents crypt hyperplasia, but normal villi; finally type III is characterized by an increasing degree of villous atrophy, as (A) partial, (B) sub-total and (C) total villous atrophy.

Subjects classified with grade 3 were diagnosed as being affected by CD.

\section{HLA-typing}

All individuals were typed for HLA-DQA1 and HLADQB1 in high resolution through nucleotide sequencing after amplification by polymerase chain reaction (PCR) from genomic DNA, extracted by salting out $\operatorname{method}^{(9)}$. Following the methodology described by Rajalingam et al. ${ }^{(13)}$, in order to sequence the HLA-DQA1 gene, it was necessary to make specific amplifications of three groups of alleles: group 1 (HLA-DQA $1 * 01$ ), group 2 (HLA-DQA $1 * 02, * 04, * 05$ and $* 06$ ) and group 3 (HLA-DQA1*03) ${ }^{(13)}$. For sequencing the HLA-DQB1, specific amplifications were made for two groups of alleles: the group consisting of HLA-DQB $1 * 02, * 03$ and * 04 and the group comprising HLA-DQB1 * 05 and * $06^{(16)}$.

The amplification products were visualized after gel electrophoresis in 2\% agarose and purified with Sephadex G-50 Fine (Amersham Biosciences). For sequencing reaction, BigDye Terminator v3.1 Cycle Sequencing (Applied Biosystems) kit was used, and the sequencer ABI PRISM 310 Genetic Analyzer (Applied Biosystems Applera, Foster City, CA) for reading the samples.

\section{RESULTS}

\section{Characterization of pediatric CD population}

Is important to note that this study was conducted at the only hospital that gives assistance to the island, therefore the results are representative of the island's pediatric population.

Thirty-nine children with diagnosis of $\mathrm{CD}$ were registered, $18 / 46 \%$ males and $21 / 54 \%$ females, age range 6 months to 17 years, median 6 years, with a median age of diagnosis of 22 months (Table 1).

TABLE 1 . Sex, age and clinical characteristics of celiac disease patients at the time of diagnosis

\begin{tabular}{lcc}
\hline & \multicolumn{2}{c}{ Patients $(\mathrm{n}=39)$} \\
\cline { 2 - 3 } & $\mathrm{n}$ & $\%$ \\
\hline Sex & 18 & 46.2 \\
$\quad$ Male & 21 & 53.8 \\
$\quad$ Female & & \\
Age at diagnosis & 2 & 5.1 \\
$\quad$ to 6 months & 11 & 28.2 \\
7 to 12 months & 19 & 48.7 \\
13 to 24 months & 7 & 18.0 \\
$\quad$ More than 24 months & & \\
Clinical form at diagnosis & 39 & 100.0 \\
$\quad$ Gastrointestinal symptoms & 27 & 69.2 \\
$\quad$ Non-gastrointestinal symptoms* & 27 \\
* Non gastrointestinal symptoms in this group: faillure to thrive, anemia, neurologic symptoms
\end{tabular}




\section{The prevalence of CD in children under the age of 18 years was $0,07 \%$}

$\mathrm{CD}$ related disorders were found in three patients - Down Syndrome, Diabetes mellitus type I, IgA deficiency, one case for each.

HLA- typing was performed in 38 celiac patients, $28 / 74 \%$ DQ2 positive, $1 / 2 \%$ DQ8 positive and 9/24\% incomplete DQ2 (presence of only one allele - DQA $1 * 05$ or DQB1*02). One patient didn't undergo HLA typing.

\section{First degree relatives}

Ninety-five first degree relatives (46/48\% females, $49 / 51 \%$ males, age range $3-55$ years, mean age 27,58 years) out of the 110 first degree relatives of the $39 \mathrm{CD}$ children agreed with the screening procedure and, after obtaining informed consent, underwent serological testing.

This 95 relatives included 58 parents $(27$ fathers and 31 mothers, aged $26-55$ years, median 37,3 years) and 37 siblings (15 sisters and 22 brothers, aged 3 to 25 , median 12 years).

Positive IgA-TGG was found in five relatives (two sisters, one brother, one father and one mother) age range 10 to 33 . Three out of these five individuals had symptoms [abdominal distension $(n=2)$ and weight loss $(n=1)]$.

Three individuals (two siblings and a father) had the presence of HLA-DQ2, whereas two were DQ2 incomplete - DQB1*02 (one mother and one sister).

Histological changes characteristic of $\mathrm{CD}$ were found in three of these five first degree relatives [type 3A (one mother) (type 3B (2 siblings)]. One father refused the endoscopic biopsy and one sister had normal intestinal mucosa. (Figure 1)

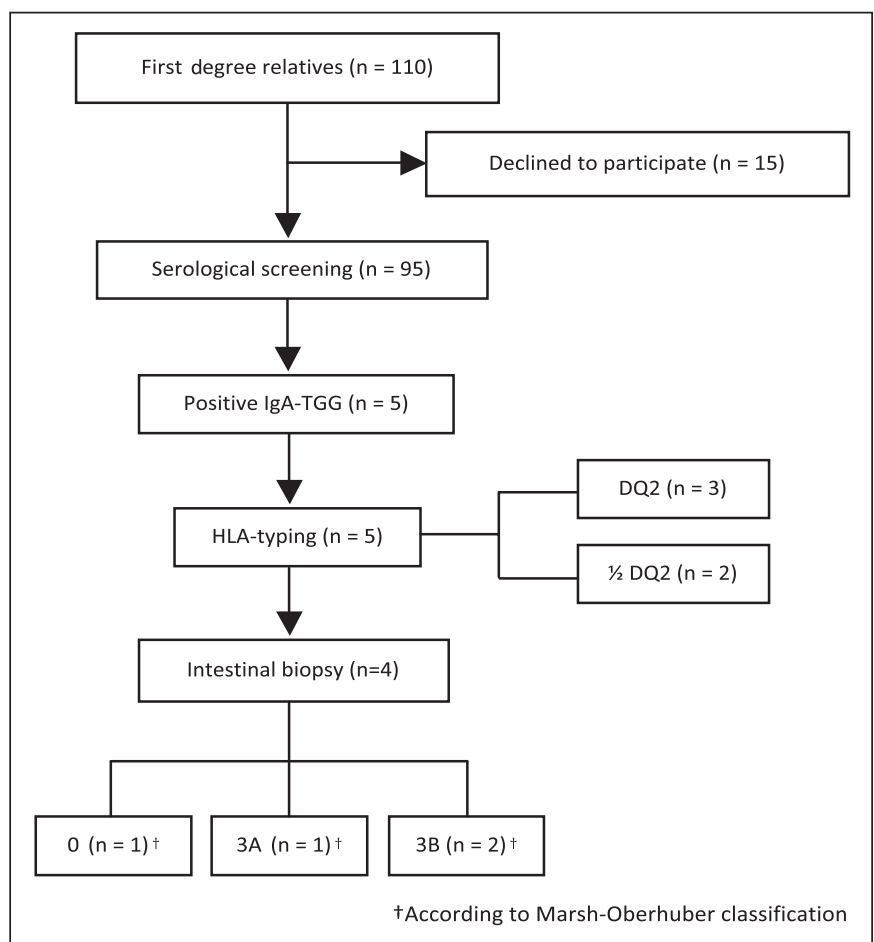

FIGURE 1. First degree relatives. Results

HLA: human leukocyte antigen

\section{DISCUSSION}

The prevalence of celiac disease in children varies considerably, from $0.02 \%$ (Kuwait) to $1.0 \%$ in European countries like Great Britain and Finland ${ }^{(14)}$. In the present study, the prevalence of $\mathrm{CD}$ in children under the age of 18 years was $0,07 \%$.

The prevalence of $\mathrm{CD}$ among the first degree relatives was $3,15 \%$ (approximately 1:31 relatives), 4.5 times higher than the proposed prevalence among the general Portuguese population $(0,7 \%)^{(2)}$ which reinforces the risk of first-degree relatives for $\mathrm{CD}$ in contrast to general population.

It is important to note that the fact that the study was conducted at the only hospital that gives assistance to Madeiran population, gives strength to the study, since the data are representative of the island's pediatric population.

Our results are similar to those found in Spain by Victoria et al. ${ }^{(15)}$ that reported a prevalence of $2,8 \%$ new cases among 642 first degree relatives of celiac patients. In the recent studies the prevalence among first-degree relatives varied between $2.6 \%$ to $9.5 \%$, a range that can be consequence of methodological differences used in these studies and the genetic background of the distinct population valued ${ }^{(1,2,5,14,15)}$. Interesting to notice that our results were similar to those from a recent study conducted in another Portuguese region (Porto) by Andreia Oliveira et al. ${ }^{(12)}$ that revealed a prevalence of $2.6 \%$ among 268 first degree relatives. A lower genetic variability typical in island inhabitants may be responsible for the slight higher prevalence found in our study.

It is important to notice that one first degree relative was characterized as with a latent form of $\mathrm{CD}$ inasmuch as she had positive serologic and genetic markers, despite absence of symptoms and normal intestinal mucosa. This patient will maintain follow up in order to assess future CD manifestations and intestinal mucosa lesions. The other relative who refused the intestinal biopsy is a potential CD patient, and the explanation of the risks of undiagnosed illness was given to the patient.

One out of the three positive relatives presented a silent form of $\mathrm{CD}$ which highlights the importance of screening all $\mathrm{CD}$ first degree relatives. The presence of one IgA deficiency child among the index cases is not surprising and corroborates the importance of assaying IgA levels for $\mathrm{CD}$ screening.

Every CD index cases carried HLA-DQ2 (complete or incomplete form) or DQ8 haplotype. The HLA-DQ2 haplotype was the most prevalent according to other published studies $^{(4,8)}$.

Each three relatives with CD also carried the HLA DQ2 haplotype, reinforcing the diagnosis of $\mathrm{CD}$.

There is only a small percentage of $C D$ patients who are negative for HLA-DQ2 and DQ8, which makes this a good exclusion test. There is some evidence that HLADQ2/DQ8 typing has a role in the case-finding strategy in individuals who belong to groups at risk of $\mathrm{CD}^{(7)}$.

Obtaining biopsies from every first-degree relatives would have enabled us to establish the true prevalence of $\mathrm{CD}$ among them, but the invasiveness and cost of the test preclude the submission of all CD relatives to this examination. For this 
reason serologic tests and HLA typing have an important role in screening potential patients.

Recent population-based studies have suggested that patients with diagnosed $\mathrm{CD}$ are at increased risk of mortality and increased risk of lymphoproliferative malignancy and gastrointestinal cancer. There is also some evidence suggesting that a gluten free diet may reduce the risk of lymphoproliferative malignancy ${ }^{(9)}$.

Hence, the acknowledgment that $\mathrm{CD}$ relatives are a population at high risk of developing gluten intolerance, suggests the need for an extensive screening policy in order to prevent complications and improve the quality of life of these individuals.

\section{ACKNOWLEDGEMENTS}

We thank Dr. Gomes Ferreira, coordinator of Gastroenterology section of Pediatric Department, Dr. Rui Vasconcelos, head of Pediatric Department, Dr. Sónia Freitas collaborator of the Investigation Unit of Hospital Dr. Nélio Mendonça. We also thank Dr. Carla Spínola, collaborator of the Laboratory of Human Genetics of University of Madeira.

Oliveira JRH, Cabral AJ, Ferreira E, Capelinha F, Spínola H, Gonçalves R. Doença celíaca em idade pediátrica na Ilha da Madeira e sua prevalência em familiares de primeiro grau. Arq Gastroenterol. 2014,51(2):151-4.

RESUMO - Contexto - A doença celíaca é uma doença sistémica autoimune muito prevalente nos familiares de primeiro grau de doentes celíacos. Objetivos - O objetivo deste estudo é determinar a prevalência de doença celíaca, num grupo de familiares de primeiro grau de crianças com o diagnóstico de doença celíaca e, determinar a frequência de antígeno leucocitário humano (HLA)-DQ2 e DQ8 nos doentes celíacos e seus familiares afetados. Métodos - Foi feita a pesquisa dos processos clínicos de 39 crianças com o diagnóstico de doença celíaca seguidas na consulta de Gastroenterologia Pediátrica do Hospital Dr. Nélio Mendonça na Ilha da Madeira, Portugal. Foram convidados 110 familiares de primeiro grau para a realização do rastreio serológico de doença celíaca através da quantificação do anticorpo IgA anti-transglutaminase tecidular humano (IgA-TGG). Aos familiares com resultado positivo no rastreio, foi recomendada a realização de biópsia intestinal e tipificação HLA. Resultados - A tipificação HLA foi realizada em 38 crianças. Verificou-se a presença do heterodímero DQ2 em 28/74\%, DQ8 em 1/2\% e DQ2 incompleto em 9/24\% das crianças. O rastreio de DC com IgA-TGG foi positivo em cinco dos 95 familiares analisados, tendo sido diagnosticada doença celíaca em três destes. Verificou-se a presença do heterodímero HLA-DQ2 em três familiares e HLA-DQ2 incompleto (DQB1*02) em dois familiares. Conclusões - A prevalência de doença celíaca em familiares de primeiro grau de doentes celíacos foi $3.1 \%, 4.5$ vezes mais elevada do que a da população Portuguesa geral $(0,7 \%)$, o que reforça a importância de alargar o rastreio a este grupo específico. A tipificação HLA pode constituir um instrumento importante na abordagem diagnóstica.

DESCRITORES - Doença celíaca. Crianças. Predisposição genética para doença. Antígenos HLA.

\section{REFERENCES}

1. Almeida PL, Gandolfi L, Modelli IC, Martins Rde C, Almeida RC, Pratesi R. Prevalence of celiac disease among first degree relatives of Brazilian celiac patients. Arq Gastroenterol. 2008.;45:69-72.

2. Antunes H. First study on the prevalence of celiac disease in a Portuguese population. J Pediatr Gastroenterol Nutr. 2002;34:240.

3. Bonamico M, Ferri M, Mariani P, Nenna R, Thanasi E, Luparia RP, et al. Serologic and genetic markers of celiac disease: a sequential study in the screening of first degree relatives. J Pediatr Gastroenterol Nutr. 2006;42:150-4.

4. Catassi C, Fasano A. Celiac disease. Curr Opin Gastroenterol. 2008 Nov;24(6): 687-91.

5. Fasano A, Berti I, Gerarduzzi T, Not T, Colletti RB, Drago S, et al. Prevalence of celiac disease in at-risk and not-at-risk groups in the United States: a large multicenter study. Arch Intern Med. 2003;163:286-92.

6. Grover R, Puri AS, Aggarwal N, Sakhuja P. Familial prevalence among first-degree relatives of celiac disease in North India. Dig Liver Dis. 2007.;39:903-7.

7. Husby S, Koletzko S, Korponay-Szabo IR, Mearin ML, Phillips A, Shamir R, et al. European Society for Pediatric Gastroenterology, Hepatology, and Nutrition guidelines for the diagnosis of coeliac disease. J Pediatr Gastroenterol Nutr. 2012;54:136-60.

8. Karrel K LAS, Moodie SJ, Ascher H, Clot F, Greco L, Ciclitira PJ, et al. HLA types in celiac disease patients not carrying the DQA1*05-DQB1*02 (DQ2) heterodimer: results from the European Genetics cluster on celiac disease. Human Immunology. 2003:469-77.
9. Ludvigsson JF. Mortality and malignancy in celiac disease. Gastrointest Endosc Clin N Am. 2012;22:705-22.

10. Miller SA, Dykes DD, Polesky HF. A simple salting out procedure for extracting DNA from human nucleated cells. Nucleic Acids Res. 1988;16:1215.

11. Oberhuber G, Granditsch G, Vogelsang H. The histopathology of coeliac disease: time for a standardized report scheme for pathologists. Eur J Gastroenterol Hepatol. 1999;11:1185-94.

12. Oliveira A, Trindade E, Tavares M, Lima R, Terra M, Dias JA. Celiac disease in first degree relatives of celiac children. Arq Gastroenterol. 2012;49:204-7.

13. Rajalingam R, Ge P, Reed EF. A sequencing-based typing method for HLA-DQA1 alleles. Hum Immunol. 2004;65:373-9.

14. Tack GJ, Verbeek WH, Schreurs MW, Mulder CJ. The spectrum of celiac disease: epidemiology, clinical aspects and treatment. Nat Rev Gastroenterol Hepatol. 2010:204-13

15. Vitoria JC AA, Astigarraga I, García-Masdevall D, Rodriguez-Soriano J. Use of serological markers as a screening test in family members of patients with celiac disease. Journal of Pediatric Gastroenterology Nutrition. 1994;19:304-9.

16. Voorter CEM KM, van den Berg-Loonen EM. Sequence-based typing for HLADQB1: Strategy for the ALF express. In: Tilanus MGJ HJ, Hurley CK, eds, editor IHWG technical manual genomic analysis of the human MHC, DNA-based typing for HLA alleles and linked polymorphisms. Seattle: Fred Hutchinson Cancer Research Center; 2000.

Received 10/10/2013. Accepted 21/2/2014 